\title{
FACTORS INFLUENCING THE EXTENT OF CORPORATE COMPLIANCE WITH INTERNATIONAL FINANCIAL REPORTING STANDARDS IN SOUTH AFRICA
}

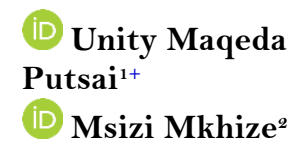

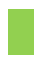

\section{Article History}

Received: 14 July 2021 Revised: 12 November 2021 Accepted: 6 December 2021 Published: 24. December 2021

\section{Keywords \\ JSE \\ Ohlson model \\ ROTA \\ Leverage \\ EPS \\ Company size \\ Profitability ratio \\ Cultural theory.}

JEL Classification:

M40, M41, M49

\author{
'PhD Student at the University of Kwa Zulu Natal, College of Law and \\ Management Studies, School of Accounting Economics and Finance, Westville \\ Campus, Durban, South Africa. \\ Email:217081984@stu.ukzn.ac.za \\ ${ }^{2}$ Professor at the University of Kwa Zulu Natal, Dean of Teaching and

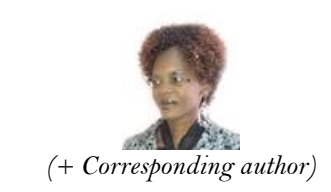
Learning, College of Law and Management Studies, Westville Campus, Durban, South Africa.

Email: Mkhizem4@ukzn.ac.za

The main objective of this study is to investigate the effects of company attributes on compliance with International Financial Reporting Standards (IFRS). The study used a sample of 46 listed companies on the Johannesburg Stock Exchange (JSE) covering the period from 1993 to 2017 . With an average compliance level of 88.21304 , it is concluded that South Africa's listed firms have significantly complied with IFRS 1. Using panel data to analyze the effects of company attributes, size and leverage have a significant positive effect on IFRS 1 compliance. On the other hand, the coefficients of Earnings Per Share (EPS) and Return on Total Assets (ROTA) are negative and significant. This similarly implies that ROTA and EPS are important factors driving the compliance level of the companies in South Africa with the IFRS 1 disclosure. EPS and ROTA also exhibit an inverse relationship with the compliance level. Carrying out a longitudinal study helps to produce more recent evidence on the quality of IFRS financial reports in South Africa. The outcome of the study is beneficial to international literature as it provides enough evidence on the benefits of adopting IFRS adoption.

Contribution/Originality: This study is one of very few studies which have investigated the factors that affect the level of compliance with IFRS, thereby providing empirical evidence that is essential to the chartered accountants who are part of corporate boards responsible for ensuring high compliance with IFRS.

\section{INTRODUCTION}

Generally Accepted Accounting Principles (GAAP) are a list of accounting rules that are followed during the preparation of financial statements. All listed companies in South Africa are duty-bound to publish their year-end financial statements (Companies Act, 2008). Financial statements play a pivotal role for investors, banks, and creditors because they reflect the financial health of a firm and contain information about whether a company qualifies for investment or a credit extension (Asika, 2018).

Every nation has formulated its GAAP, and publicly released financial reports should abide by the rules. According to IFRS 1, financial reports contain high-quality information which should be transparent for all stakeholders, be comparable all over the world, provide a strong and suitable foundation for presenting the 
transactions according to the IFRS, and be presented at a cost that does not outweigh the benefits. In this study, IFRS 1 is included in the analyses.

The correlation between disclosure of information about financial accounting standards and company performance is a topic of contemporary research. Previous studies on developed and less developed nations have produced robust evidence of firms' levels of disclosure under IFRS as this affects performance. Despite several studies that were carried out on the topic of compliance, there has been no convergent outcome on the relationship between a company's performance and its level of disclosure (Ofoegbu \& Odoemelam, 2018).

In the present research, the theoretical framework facilitated the identification of firm characteristics which are relevant to the degree of compliance with IFRS. A literature review was also carried out on formulating and consequently testing the hypotheses linking corporate characteristics and IFRS level of compliance.

\subsection{Research Problem}

Very few studies have been carried out concerning the presentation of financial statements in South Africa. Dzomira (2015) investigated corporate governance as well as fraud risk management of listed companies in South Africa based on a qualitative research approach. The findings showed that there was a lack of good corporate governance in South Africa, particularly for financial and performance reporting and also on compliance with IFRS. The author recommended that more studies on financial statement reporting should be carried out. Based on the recommendations by Dzomira (2015), the current study contributes to the existing literature.

The Financial Market Act (2012) states that all public companies must abide by all the JSE listing requirements. The act reveals that companies will be suspended from the JSE for the following reasons: any fraudulent activities on financial statements, liquidation, non-compliance of listing rules, and failure to submit the year-end financial reports on time. According to Tran, Ha, Le, and Nguyen (2019), improving the quality of financial information through high compliance with IFRS can inject capital into companies that can improve business performance. In addition to that, high-quality financial statements can enhance top management performance thereby improving the value relevance of financial accounts. Therefore, this study can provide recommendations and advice to help mitigate the liquidation of companies, which is happening to public companies in South Africa due to lack of capital.

\section{LITERATURE REVIEW}

\subsection{Compliance with IFRS}

It is mandatory to disclose the annual financial statements that are compiled, according to IFRS. The information published in the financial statements should be value relevant to the user and satisfy their needs. An explanation of all the transactions should be also disclosed in the financial reports. The Companies Act (2008) explains that companies should always publish comparable financial information from the previous and current years. Comparability allows the stakeholders to analyze the performance of companies. Therefore, the Companies Act (2008) encourages companies to comply with IFRS 1 disclosure requirements.

Pacter (2016) documented that the major purpose of IFRS is to strengthen accountability thereby mitigating the information gap that exists between the injectors of capital and the management of companies. Also, the standards require information that is essential for managers of firms to be accountable. Pacter (2016) further stated that IFRS plays a pivotal role in the economic efficiency of companies by assisting potential and existing investors to recognize opportunities and risks in all nations, thus enhancing the allocation of capital.

\subsection{The Determinants of Corporate Attributes}

Al Mutawaa and Hewaidy (2010) investigated the disclosure and compliance levels of IFRS in Kuwait. In their study, the following company attributes were used: industry type, type of auditor, company age, liquidity, and 
leverage. The authors stated that, in terms of the type of audit, it is assumed that the "Big Four" auditing firms have higher compliance than those audited by small private auditing firms because the former employ more highly qualified auditors who are professionals and experts in compliance. After analyzing the abovementioned firm attributes, the findings reflected that company size, type of industry, audit size, and profitability are positively and significantly associated with the degree of IFRS compliance. On the other hand, leverage is negatively associated with compliance to IFRS.

Glaum, Schmidt, and Street (2013) analyzed the levels of compliance of 17 European countries with IFRS 3 and IFRS 36. In the study, company level, auditor type, audit committee, ownership structure, and financial services were utilized as the company attributes. Apart from these attributes, the study also considered external factors such as country level and national culture, which are irrelevant in this current study. Company level is measured by the value of goodwill. The outcome revealed that company level, ownership structure, and the type of auditor are positively associated with compliance with IFRS 3 as well as IFRS 36.

In Vietnam, Tran et al. (2019) investigated the factors that affect IFRS adoption and compliance level. In their study, they analyzed the following company attributes: firm size; debt ratio; profitability ratio, which is the return on equity; audit quality; and foreign operation. They also explained that companies with higher earnings comply with IFRS in order to disclose their profits. In the study, it was assumed that large firms are linked to a higher level of compliance with IFRS compared to small companies. The findings reflected that foreign ownership, return on equity, company size, and audit quality all have an influence on the adoption of IFRS, thereby affecting the level of compliance. The debt-to-equity ratio is not associated with the adoption of IFRS, therefore it does not affect the compliance level. Tran et al. (2019) documented that the companies that make huge profits have a higher level of compliance so that they can prove to investors that their earnings are reliable. Additionally, the issue of earnings is fundamental during the presentation of IFRS.

According to Tulsian (2014), profitability ratios are calculated to investigate the efficiency of a company and the present operating performance of management as well as enabling a comparison between two or more firms. Also, the efficiency of a company cannot be measured by profit only, thus high profit does not always highlight good corporate performance, nor is low profit a symbol of organizational turmoil. The author further stated that profitability ratios should be utilized together with other ratios. In this present study, profitability is measured using the EPS and ROTA ratios.

Tang, Fu, and Yang (2019) stated that large companies tend to disclose higher quality information than their rivals. Big organizations are highly leveraged because they disclose information according to IFRS disclosure requirements. A stakeholder needs to check the leverage level of a company because when the debt is escalating, banks and other financial institutions become a more significant influence and tend to monitor the financial information (Jensen \& Meckling, 1976).

In Ghana, Blay, Gudjoe, and Okyere (2019) investigated the level of compliance with IFRS. Using a sample of 67 firms in the Cape Coast Metropolitan, the author compiled a checklist and further analysed the company attributes which are as follows: the size of a firm, profitability, type of auditor, internationality, and leverage. The outcome revealed that the level of compliance with IFRS is $77.9 \%$. Also, among the company attributes only the profitability and auditor type are positively correlated to compliance with IFRS. ROTA and EPS are the two ratios that are included in the study.

In Romania, Ponce, Hlaciuc, Mateș, and Măciucă (2016) analyzed the financial disclosure with IFRS in public companies. The findings showed that company size has a partial influence on the level of IFRS disclosure compliance. According to Ponce et al. (2016), company size is one of the variables that is used to measure the level of compliance with the IFRS. The authors highlighted that most of the studies found evidence that company size is significantly associated with IFRS compliance. Ponce et al. (2016) highlighted that big firms, such as the World Bank and the IMF have a strong influence on the degree of compliance with the IFRS. 
In the USA, Myšková and Hájek (2017) investigated company performance using accounting ratios. In their study, profitability, cash flow, leverage, and other market indicators were used as the company attributes. The authors explained that it is preferable to employ several attributes to capture the interest of investors. The findings reflected that financial ratios are preferable to other the variables used in the study to measure performance.

In Turkey, Uyar, Kilic, and Gokcen (2016) investigated the compliance level of Turkish public firms as well as the effect of the company attributes. The authors measured the compliance level and then analyzed the following attributes: staff training, size of the company, leverage, profitability, and foreign ownership. Training of employees is fundamental because it enhances understanding of the complicated common standards, thereby improving the level of compliance (Uyar et al., 2016). Additionally, the listing status of firms is pivotal and companies are grouped according to whether they are registered on the home country stock exchange or listed on both the home country as well as a foreign stock exchange. The study revealed that a company that is listed on both home and foreign stock exchanges incur higher agency costs than a country which is listed in just the home country. Companies operating in both foreign countries and their home country try to mitigate the agency costs by complying with IFRS. Also, listed companies' accountants tend to be more knowledgeable than those in small companies in terms of compiling financial reports. The findings show that the listing status, training of employees, and company size are significantly correlated with compliance with IFRS, whereas leverage and profitability are not.

In Nigeria, Ibrahim (2015) analyzed the effect of company attributes on compliance with IFRS. The author used a sample of 97 companies listed on the Nigerian Stock Exchange. The firm characteristics that were employed during the investigation are category of industry, class of auditor, size of the company, and the duration of the listing. The study also used a checklist for the level of compliance. In Nigeria, Ibrahim (2015) found that all the company attributes listed above are positively associated with compliance with IFRS 8.

In Macedonia, Atanasovski (2015) used the disclosure index and company characteristics to assessed the level of compliance with IFRS 7. The following determinants were analyzed: company size, audit type, ownership concentration, and profitability. The findings reflected that audit type and ownership concentration have a strong influence on the level of compliance with IFRS 7.

In Nigeria, Chukwu, Damiebi, and Okoye (2019) investigated how firm-specific attributes, such as company size, liquidity, and leverage, affect the value relevance of accounting information. Using a sample of 54 companies listed on the Nigeria Stock Exchange, the study employed the Ohlson (1995) model. The findings indicated that firm-specific characteristic affect the financial operation of a company. To enhance the market value of companies, great improvements are required regarding firm size, liquidity, and leverage.

On the other hand, in Poland, Rutkowska-Ziarko (2015) investigated the effect of the size of a company on financial performance. In this study, profitability ratios were used to measure financial performance. The study documented that the size of a firm is negatively correlated with its financial performance, particularly the risk of stock market investments and the volatility of profitability ratios.

From the abovementioned literature, there are no specific company attributes that are linked to compliance with IFRS. Company attributes changed according to each study; therefore, further research is still needed to fill the gap in that area. Also, the previous studies documented mixed findings on the effect of company attributes on financial reports. The findings of this current study will help to clarify the relationship between company attributes and compliance with IFRS 1 in South Africa.

\subsection{Compliance with IFRS 1}

In Ghana, Yiadom and Atsunyo (2014) analyzed the degree of compliance with IFRS and also investigated the correlation between firm attributes and compliance level. The findings showed that company size, profitability, audit size, internationality, and industry type have a positive effect on the degree of compliance. It was further noted that compliance level differed from one company to another. According to IFRS 1, the harmonization of the 
common standards is for comparability purposes. Therefore, companies that adopted IFRS must have the same compliance level if they have properly implemented the standards. It is therefore necessary to check the compliance level of companies in South Africa. In order to meet the objective of this study, five hypotheses were developed.

H1: South African public companies significantly comply with IFRS 1.

\subsection{Firm Attributes Hypotheses}

Frankfort-Nachmias and Nachmias (2008) argued that correct speculation ought to be testable and expressly stated. Prior literature documents mixed findings on the link between IFRS compliance and firm characteristics. According to Agyei-Mensah (2012), to examine the level of compliance with IFRS 1 in the financial statements, the independent variables/firm characteristics must be tested. This study tested the following: leverage, EPS, ROTA and company size.

\subsection{Leverage}

According to Ofoegbu and Odoemelam (2018), high disclosures by the management of firms reduce information asymmetry as well as agency costs. The authors stated that agency cost describes the correlation between leverage and disclosure. Latridis and Dalla (2011) found a positive correlation between leverage and the implementation of IFRS. On the other hand, Uyar et al. (2016); Ofoegbu and Odoemelam (2018); Adenugba, Ige, and Kesinro (2016) and Aggreh, Malgwi, Aggreh, and Enyi-Igbokwe (2018) found no association between leverage and compliance with IFRS. Adenugba et al. (2016) highlighted that leverage is a better source of income than equity when it comes to financing long-term projects.

H2 Leverage has a significantly positive effect on IFRS compliance.

\subsection{Profitability (ROTA and EPS)}

Agyei-Mensah found that high profitability sends a good signal to the market, unlike the companies operating at a loss. According to IFRS 1, all public firms are entitled to publish their sources of finance. For Ponce et al. (2016), profitability is the most commonly used variable to assess the relationship between the accounting disclosure checklist and return on equity (ROE). They also explained that the positive relationship that exists between profitability and compliance is that a company's management has the freedom and flexibility to undertake and disclose more extensive social responsibility schedules to both external and internal shareholders. Consistent with Latridis and Dalla (2011), there is a positive correlation between profitability and compliance with IFRS. In their study, Ponce et al. (2016) showed that there is no dependency between ROE and the level of compliance. On the contrary, Tsegba, Sember, and Tyokoso (2017) argued that profitability is significantly related to the degree of compliance.

Using a sample of 305 disclosure requirements extracted from the Jordanian companies listed on the Amman Stock Exchange, Khamees (2018) investigated the effect of compliance on IFRS earnings. In the study, EPS is one of the independent variables. The author calculated the compliance score, which was then used for statistical measures. The findings reflected that high compliance with IFRS harms expected earnings, meaning that a high level of disclosure could allow investors or other stakeholders to depend on other market indicators rather than EPS.

Following the aforementioned outcomes, the following hypotheses are tested:

H3: Return on total assets (ROTA) is positively correlated with the level of compliance offinancial information.

H4: Earnings per share (EPS) is positively associated with compliance of financial information. 


\subsection{Company Size}

Several researchers have identified corporate size as positively associated with the degree of compliance with IFRS (Al Mutawaa \& Hewaidy, 2010; Atanasovski, 2015; Latridis \& Dalla, 2011; Ofoegbu \& Odoemelam, 2018). According to Al Mutawaa and Hewaidy (2010), corporate size is measured either by total assets or total sales. On the other hand, Tsegba et al. (2017) stated that the size of a company is insignificantly associated with the level of IFRS compliance. The above contradicting findings led to the following hypothesis:

H5: Company size has a significantly positive effect on IFRS compliance.

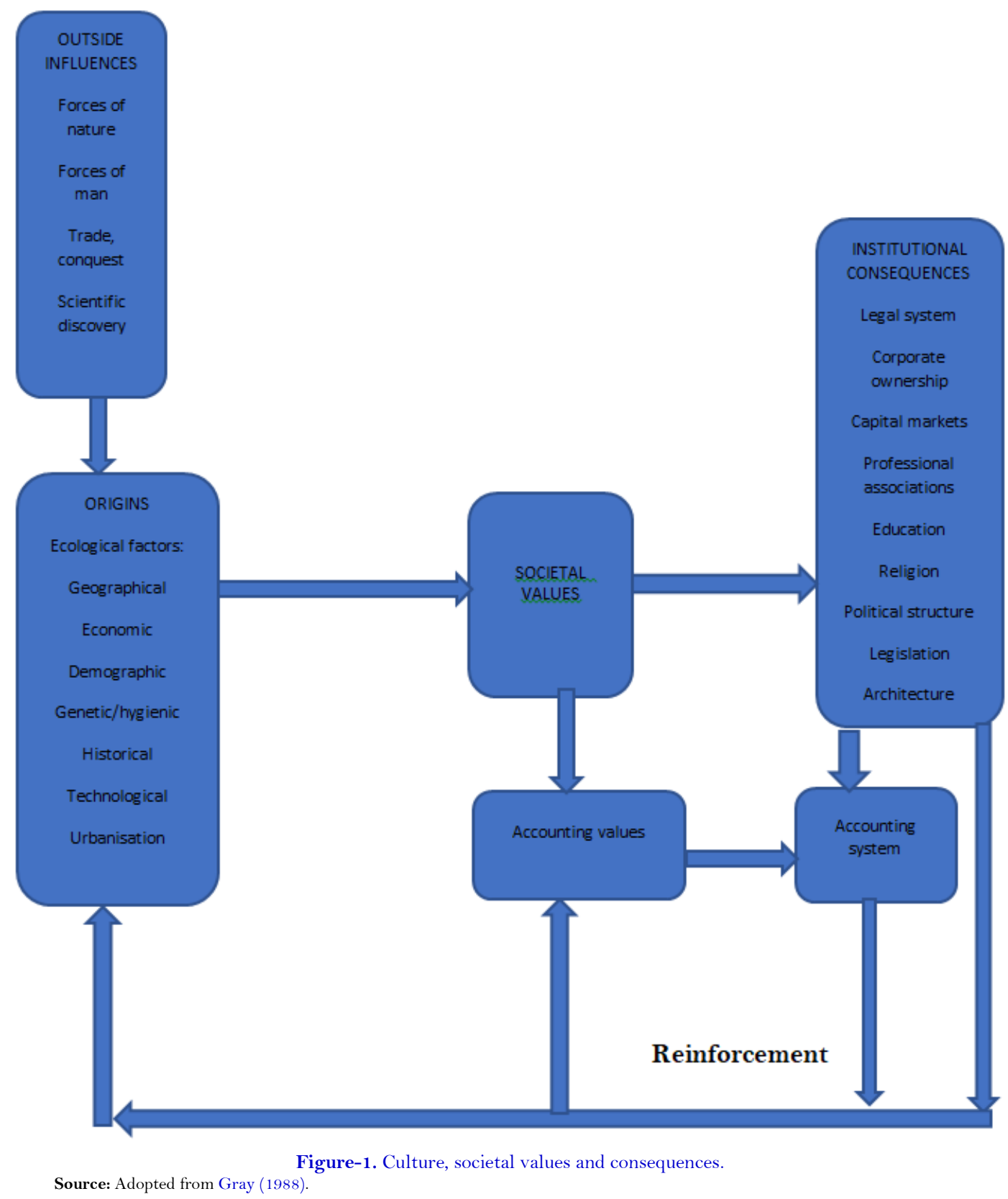

\subsection{Cultural Theory}

According to Hofstede (1983), culture can be described as a collective programming of the mind, difficult to change, and differentiates a group of humans from others. Also, it is very difficult to implement changes to cultural programming unless some people move away from their culture. (Hofstede, 1983) employed cultural theory which illustrates the coordination of: 
- External environmental factors, such as forces of man and scientific discovery.

- Ecological factors, such as urbanization and technological factors.

- Economic factors.

- Institutional consequences, such as company ownership, company size, and professional associations, in value creation.

Hofstede (1983) also mentioned that the four factors listed above have a very strong influence on the development of cultural theory.

\subsection{Linking Cultural Theory with IFRS Adoption}

Gray (1988) extended Hofstede's Cultural Dimensions Theory to demonstrate the connection between the culture of an organization and the development of its accounting system.

Figure 1 above summarizes how Gray (1988) linked cultural theory to the accounting system. Gray (1988) analyzed the link between culture and accounting systems by using accounting literature and cultural theory reasoning. The author explained how the accounting system is weakened by professional and regulatory structure that emanate from the cultural base. Gray (1988) then formulated the four accounting value dimensions and scrutinized the effect of a country's culture on accounting practice. Furthermore Gray (1988) described the type of accounting system that is found in countries with different cultures. In other words, culture compromises the comparability of financial reports, which is one of the stated goals of the IASB. According to Gray (1988), the following are the determinants of the accounting system: professionalism, such as audit companies; statutory controls, such as tax; conservatism; optimism; secrecy; transparency when compiling the financial reports; uniformity (which is the major reason for implementing IFRS); as well as flexibility. Gray (1988) is summarized in Figure 1.

(Cardona, Karen, Castro-Gonzalez, \& Carmen, 2014) investigated the effect of culture and economic factors on the compliance of IFRS, and the findings reflected that some cultural dimensions and economic factors influence the implementation of IFRS. Akman (2011) stated that the implementation of IFRS does not fully eliminate the effect of culture on disclosure of the common standards. According to Masca (2012), the level of compliance with IFRS is determined by the accounting culture of the geographical area in which the firms operate. In Gray (1988), cultural dimension was recommended by Borker (13b) to be utilized as a baseline to analyze the factors affecting IFRS adoption in organizations.

Zehri and Chouaibi (2013) stated that different nations are influenced by the Anglo-Saxon culture of transitioning to IFRS, which is a more advanced and sophisticated accounting system. Also, the adoption of the common standards was complicated for both developed and less developed nations with Anglo-Saxon culture. Zehri and Chouaibi (2013) further disclosed that for the last two decades the Anglo-Saxon culture has strongly affected national cultures.

Cultural theory helps to clarify the effect of company attributes on financial statements. On the other hand, cultural theory does not clarify the relationship between company attributes and the disclosure of financial accounts. The current study contributes to the theory by measuring the association between company attributes and compliance with IFRS; for instance, whether a company attribute has a positive significant association with the presentation of IFRS financial reports or a significant negative association.

\section{METHODOLOGY}

The study utilized 46 public firms listed on the Johannesburg Stock Exchange. The research time frame is 1993 to 2017 (12 years before and 12 years after IFRS). During the pre-IFRS regime from 1993 to 2004, there was no IFRS 1. The IFRS Foundation (2012) stated that IFRS 1 was formulated by the IASB and issued in 2003. IFRS 1 
was introduced in early 2004. The sampled companies started implementing IFRS 1 in 2005. The year 2005 was excluded from the sample because it was considered as the year of transition. Data was extracted from the financial reports of the listed firms on the Johannesburg Stock Exchange (JSE) and from Bloomberg. The research is based on quantitative data. To provide answers to the research questions, the study uses the unweighted disclosure index by Cooke (1992) to calculate the level of compliance with IFRS 1 of public firms in South Africa. To investigate the association between compliance with IFRS 1 and the firms' attributes (leverage, EPS, ROTA and the company size) panel data is used for the analyses. Following (Tsegba et al., 2017), the multiple regression model is used to analyze the effect on the company's attributes on compliance with IFRS. This current study adopted the disclosure checklist used by (Nwoye, Chidoziem, Obierah, \& Ekesiob, 2017). Some alterations were made to the checklist to suit the South African condition and 56 disclosure requirements were used. In this study, a company is not penalized for changing the disclosure of any transaction following the IASB requirements, but the changes must be highlighted. South Africa adopted IFRS without amendments and all listed companies must comply and be consistent with the common standards (Pacter, 2014). Wadesango, Hove, and Kurebwa (2016) highlighted that in the objectives of IFRS it is stated that there is a significantly positive relationship between compliance with the common standards and enhancing the quality of the financial reports.

\subsection{Unweighted Disclosure Index/Dichotomous Method}

The unweighted disclosure index/dichotomous method was formulated by Cooke (1992). According to Cooke (1992), the method regards all the disclosure elements as the same. A company would get a mark of "1" for complying and "O" for not complying. Some changes were made to IFRS 1 by the IASB where companies are entitled to disclose the changes in the financial reports to qualify for a mark of "1". For instance, if a company incurred some losses and the profit before tax for the year is 0 , then the company must not leave a blank space for the profit section and instead " 0 " must be reflected so that it qualifies for a mark of " 1 ". If a company failed to disclose the changes in the financial reports, then the company would automatically be given a "O". The author and two other accounting experts manually checked the compliance level of the 46 companies thereafter and used MS Excel to calculate the average compliance level for the period.

\subsection{Level of Compliance}

Following Sarea, Muslih, and Hawaldar (2017), the level of compliance is divided into three stages reflected in the Table 1.

Table-1. Degree of compliance.

\begin{tabular}{c|c}
\hline Degree of compliance & \% \\
\hline High & 80 to 100 \\
\hline Medium & 60 to 79 \\
\hline Low & o to 59 \\
\hline
\end{tabular}

Table 1 shows the degree of compliance according to the percentages. A low percentage is $0-59$ which is not desirable, followed by 60-79, which is good but could be improved to 80-100 percent. Companies that are performing well scored between 80 and 100 , which is desirable.

According to Ofoegbu and Odoemelam (2018), the dichotomous method is easy to comprehend and it is highly recommended for investigating the compliance level with IFRS.

$T C M P L_{J}=T=\sum_{i=1}^{n} d_{i} / M=\sum_{i=1}^{m} d_{i}$

$T C M P L_{j}: \quad$ Aggregate compliance score for each company $(0 \leq \mathrm{TC} \leq 1)$, 
$\mathrm{T}:$

M:

Aggregate number of elements disclosed $d_{i}$ by the quoted firm $\mathrm{j}$.

The total figure of applicable disclosure items for company $\mathrm{j}$ that could be disclosed in the financial statement.

In summary, $\boldsymbol{T C M P L _ { J }}=\frac{\boldsymbol{T}}{\boldsymbol{M}}$

$\boldsymbol{T C M P L _ { J }}=$ disclosure checklist compiled from IFRS 1 and is used as the dependent variable.

The variables that were considered in this study were based on the availability of data and should be measured reliably and obtained from dependable sources. They should also provide answers to the research questions. The chosen variables are of paramount importance in the South African context.

Compliance level $\left(T C M P L_{J}\right)=\mathrm{f}($ company size, EPS, ROTA and leverage).

Following Tsegba et al. (2017), the following multiple regression model is used to analyze the effect of a company's attributes on compliance with IFRS. After obtaining the degree of compliance with IFRS for every company, the next step is to analyze the correlation between the level of compliance with the IFRS 1 disclosure checklist and the company's attributes so that we can reveal why firms differ as far as compliance level is concerned.

The compliance level $\left(\mathbf{T} \boldsymbol{C M P L} \mathbf{L}_{J}\right)$, which is obtained from the disclosure checklist, was compiled from IFRS 1 and is regarded as the dependent variable in a multivariate regression model. The firm attributes that are included in the multivariate regression are company size, profitability, ROTA, and leverage.

$\left(T C M P L_{J}=\propto_{0}+\beta_{1} C O M P i+\beta_{2} E P S i+\beta_{3} R O T A i+\beta_{4} L E V i+\varepsilon_{i}\right.$

TCMPL $\quad$ Total compliance.

$\propto_{0}: \quad$ Constant term.

$\beta_{1-4}:$ Coefficient.

COMPi : $\quad$ Total assets at the end of the year.

PROFi : $\quad$ Earnings before interest and tax divided by total assets.

ROTAi : $\quad$ Return on total assets at the end of the year.

LEVi : $\quad$ Total debt divided by total equity.

$\varepsilon_{\tilde{i}}: \quad$ Error term.

The significant positive coefficient of $\left(T C_{J}\right)$ reflects higher compliance and provides support for hypotheses H1-H5. An examination of the components of the above-stated compliance regression model shows the compliance level as an explanatory variable reflecting the possible relationship between variables. Leverage, EPS, ROTA, and 
company size are the explanatory variables in the regression compliance model above. These explanatory variables capture the effects they have on the compliance level of IFRS financial reports.

\subsection{Leverage}

Blaao (2016) described the leverage ratio as the amount of equity in comparison to debt. The author also highlighted that leverage ratio can be calculated using the amount of earnings in comparison to the debt of a company.

Leverage ratio $=\frac{\text { Total debt }}{\text { Total equity }}$

$\mathrm{Li}$ and Wang (2019) investigated the change in capital structure and market competitiveness. The findings reflected that the product market competitiveness is affected by the capital structure, particularly for changes in leverage. An increase in leverage is a symbol of sufficient capital, which is recommended for the growth of capital and helps firms to secure a dominant position in the market. The authors also highlighted that an increase in leverage reflects an increase in the interest expense and a decrease in future financing capacity, which compromises the future success of a company.

$\mathrm{Li}$ and Wang (2019) pointed out that companies should maintain high and low leverage levels because leverage should increase reasonably to avoid liquidity. Also, companies are encouraged to maintain a debt level lower than the industry average. However, investors do not prefer companies with a high leverage ratio. On the other hand, Mutawaa (2010) investigated the disclosure and compliance level of IFRS in Kuwait using a variety of company attributes. The findings of the study reflected that leverage is negatively associated with the compliance of IFRS.

\subsection{Profitability Ratios}

Profitability is defined as a firm's ability to generate profit after a certain period, in most cases annually (Kartikasari \& Merianti, 2016). Kartikasari and Merianti (2016) also measured profitability using return on assets (ROA). The authors stated that the major objective of operating a company is to make a profit, which is an indicator that a company is performing well financially. Kartikasari and Merianti (2016) further explained that the performance of a company is reflected in the financial statements after a certain period.

Ghebregiorgis and Atewebrhan (2016) pointed out that the profitability ratio is normally calculated annually after obtaining feedback on the use of the company resources. Blaao (2016) stated that profitability ratios are high profitability indicators that point to greater interest rates, huge credit size, as well as the diversity of operations of a firm. Additionally, high profitability reflects an increase in a firm's volume of transactions and gains and losses resulting from interest rate fluctuations.

In this study, profitability ratio was chosen because profitability is of paramount importance, particularly for financial management decisions (Garg, Tiwari, \& Shalini, 2018). The profitability of a company is also used as a major decision-making tool to predict and comprehend the overall efficiency of a firm. ROTA is a widespread measure that was also used by many researchers to analyze the profitability of a firm (Fuertes-Callen \& CuellarFernandez, 2019; Ghebregiorgis \& Atewebrhan, 2016), and is calculated by dividing earnings before interest and tax by total assets, which is done using the following formula: 


\subsection{Company Size}

According to Tsegba et al. (2017), company size is measured by total assets. In Indonesia, Yuliza (2018) analyzed the effect of company size on EPS and the share price (SP). Using a sample of 45 companies listed on the Indonesian Stock Exchange, the findings reflected that company size could moderate the relation between EPS and SP. The study also evidenced that information about the size of a firm can help investors and potential investors to make informed decisions.

Using 96 firms listed on the Tehran stock exchange, Ghafoorifard, Sheykh, Shakibaee, and Joshaghan (2014) investigated the association between the company size, age, and financial performance. The authors utilized the linear regression model as well as the SSPS software in order to test the research hypothesis. The outcome confirmed that there is a significant association between a company's size, age, and financial performance.

\section{PRESENTATION AND INTERPRETATION OF RESULTS}

This objective focuses on two aspects of compliance level, the first is to assess the compliance level and the second is to investigate the impact of company attributes on the compliance level.

\section{Compliance Level}

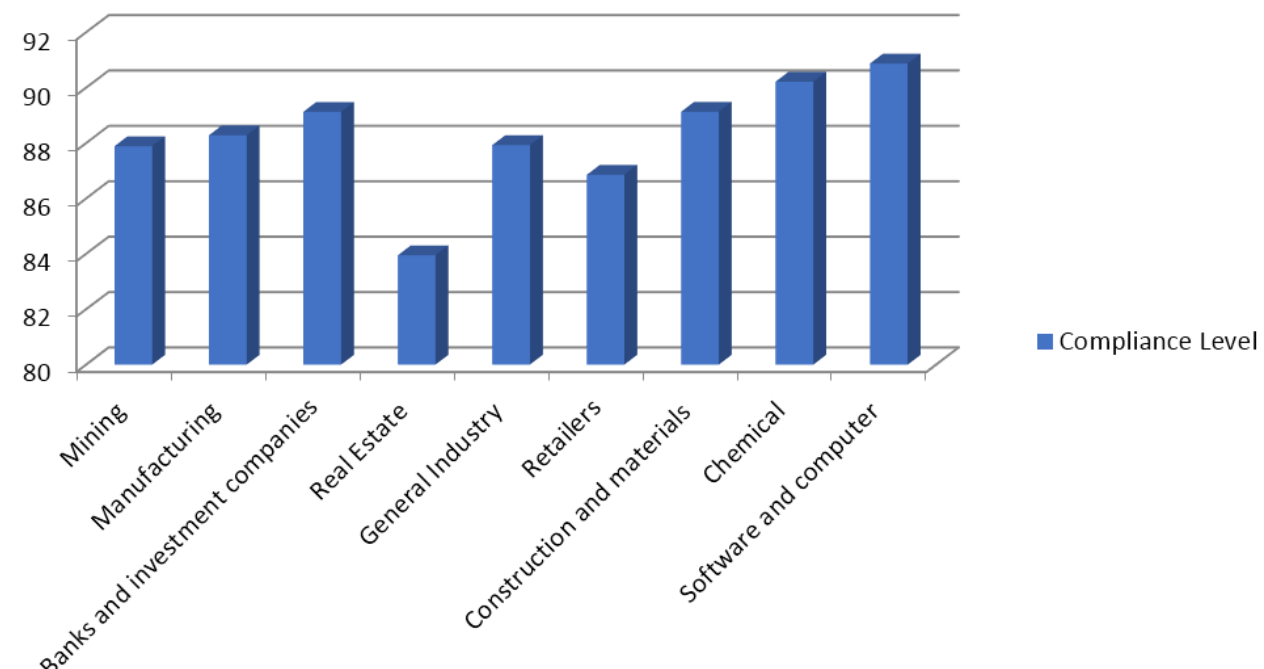

Figure-2. IFRS 1 disclosure compliance level.

Figure 2 shows the average compliance levels according to various sectors and companies that are included in the survey after the implementation of IFRS, from 2006 to 2017. All of the 46 listed companies in South Africa have between $80 \%$ and $100 \%$ compliance levels. Notwithstanding, companies in the software and computer sector have the highest compliance levels compared with other companies in the study. This is shown in Figure 2 where the average compliance level in software and computer sector is about $90.87 \%$, this is closely followed by the companies in the chemical sector with a $90.2 \%$ compliance level. Despite meeting the "high" compliance ranking of $80 \%$ on the compliance scale, companies in the real estate sector have the lowest average compliance level of about $83.9 \%$ compared to other sectors. In general, only a few companies out of the 46 recorded compliance levels below $80 \%$ during the period under review.

In this study, the findings show that South Africa is one of the African countries with high compliance in terms of the implementation of IFRS. Tsegba et al. (2017) investigated the level of compliance with IFRS in Nigeria. The findings reflected that the sampled firms have a high compliance level of 85.9\%. Alrawahi and Sarea (2016) analyzed the compliance level with IFRS 1 by listed companies on the Bahrain Bourse, and the level of compliance was revealed to be $83 \%$, which is also a favorable level. 
Table-2. Average compliance levels across sectors and companies.

\begin{tabular}{l|c|c|c}
\hline Sectors & Number of companies & Average compliance level & Remark \\
\hline Mining & 6 & 87.88667 & High \\
\hline Manufacturing & 3 & 88.28 & High \\
\hline Banks and investment companies & 7 & 89.12571 & High \\
\hline Real Estate & 3 & 83.94667 & High \\
\hline General Industry & 9 & 87.92444 & High \\
\hline Retail & 7 & 86.85143 & High \\
\hline Construction and materials & 4 & 89.13 & High \\
\hline Chemical & 3 & 90.21333 & High \\
\hline Software and computer & 4 & 90.87 & High \\
\hline
\end{tabular}

Table 2 shows the compliance levels with the IFRS 1 disclosure across various sectors and companies in South Africa. The overall result indicates that the compliance level is high. The average compliance level for all 46 companies covered in the study is 88.21304 , which indicates a high compliance level. The implication of this result is that the majority of South African companies comply with the disclosure format prescribed by IFRS 1. A total of 56 elements are stipulated in the disclosure list by the IFRS and the result from this analysis has shown that the listed companies in South Africa largely comply with these elements and revealed them in their annual financials. This result is also presented in Figure 2 above.

\subsection{Panel Data Analysis of the Impacts of Company Attributes on the Compliance Level with IFRS 1 Disclosure}

The impressive result recorded regarding the compliance level among South African companies could be dependent on some company attributes. Consequently, this section explores the role of each of the attributes, such as company size, profitability, leverage, and return on total assets (ROTA). Panel data estimation techniques are adopted to achieve this objective. However, the application of panel data requires some descriptive statistics as well as pre-estimation tests. Previous studies also used panel data (Alade, Olweny, \& Oluoch, 2017; Tawiah \& Boolaky, 2019; Usman \& Ndagi, 2019).

\subsection{Descriptive Statistics of the Company's Attributes and Compliance Level}

The descriptive statistics explored in this analysis are the summary of statistics and the correlation matrix, both of which are computed for all the variables included in the panel data analysis. The summary of statistics computes the mean and variances to enable us to determine the distribution of data across various cross-sectional units and the series. The results of the descriptive statistics are presented in Table 3.

Table-3. Summary of statistics for company attributes and compliance levels.

\begin{tabular}{c|c|c|c|c|c}
\hline & CS & EPS & Leverage & ROTA & TC \\
\hline Mean & 88267.12 & 13.84800 & 9.357956 & 91.92171 & 84.00000 \\
\hline Maximum & 251148.0 & 57.00000 & 84.77412 & 828.0079 & 97.00000 \\
\hline Minimum & 507.0000 & 0.500000 & 0.605429 & 0.054691 & 77.00000 \\
\hline Std. Dev. & 80028.24 & 13.54623 & 18.50363 & 210.6560 & 6.666231 \\
\hline Observations & 1150 & 1150 & 1150 & 1150 & 1150 \\
\hline
\end{tabular}

The summary of the statistics of all the variables included in the analysis is presented in Table 3 . The mean of the compliance level is 84 , which is closer to the maximum limit. The implication is that the compliance level for all the companies included in the analysis is high on average during the period under investigation. The mean of ROTA is 91.92171 , which is positive but closer to the minimum limit, and this is an indication that, on average, the return on assets for all the companies covered in the study might not be all that impressive. The same result is recorded for the leverage, whose mean is 9.357956. Again, the maximum limit is 84.77412 , while the minimum is 0.605429. The mean of leverage is also closer to the minimum, which signifies low leverage level across the 46 
companies during the same period. The same results are also recorded for company size and earnings per share. Their means are all closer to the minimum levels rather than the maximum levels.

For the variance analysis, the results in Table 3 show that the variances for all the variables are generally low and their values are closer to the minimum limits. The implication is that the data on all the five variables included in the panel data analysis are not widely dispersed. This confirms a good fit for the data distribution and makes it more suitable for the panel data analysis. The correlation and covariance matrix results presented in Table 4 show that there is no high degree of correlation between any two variables that are included in the analysis, hence there is no problem of multicollinearity in the estimated panel results. Again, the relationships among the variables are displayed in the correlation table. For instance, the correlation coefficient between compliance and EPS is 0.479448. This is an indication of the likelihood of an inverse relationship between the two. Similarly, compliance and ROTA show a correlation coefficient of -0.224151; the relationship between the two is also negative or inverse. However, the most important implication drawn from the covariance/correlation table is that there is no evidence of the existence of a multicollinearity problem in the model specified to be estimated with the panel data analysis, hence the results from the panel data are much more reliable.

Table-4. Correlation/covariance matrix for company attributes and compliance levels

\begin{tabular}{c|c|c|c|c|c}
\hline \multicolumn{2}{c|}{ Covariance } & & & & \\
\hline Correlation & CS & EPS & Leverage & ROTA & TC \\
\hline CS & $6.40 E+09$ & & & & \\
\hline & 1.000000 & & & & \\
\hline EPS & -5045.378 & 183.3409 & & & \\
\hline LEVERAGE & -0.004658 & 1.000000 & & & \\
\hline & 0.088607 & -0.015726 & 1.000000 & & \\
\hline ROTA & -6398176. & -173.7105 & -541.3973 & 44337.38 & \\
\hline & -0.379854 & -0.060927 & -0.139015 & 1.000000 & \\
\hline TC & -50131.24 & -52.28000 & 9.469240 & -314.4976 & 44.40000 \\
\hline & -0.094051 & -0.479448 & 0.076834 & -0.224151 & 1.000000 \\
\hline
\end{tabular}

\subsection{Panel Unit Root Test of Company Attributes and Compliance Levels}

All the variables included in the panel data analysis must be stationary; therefore, the panel unit root test is conducted to assess the stationarity of the series that are used in the model. For the sake of consistency, more than one panel unit root test methods are applied-the IPS and ADF versions of the panel unit root tests. The results are presented in Table 5 .

Table-5. Panel unit root test for impacts of company attributes on compliance level.

\begin{tabular}{c|c|c|c|c}
\hline Variables & \multicolumn{2}{|c}{ IPS unit root test } & \multicolumn{2}{c}{ ADF Fisher Chi-square unit root test } \\
\hline & t Statistics & Order of integration & t Statistics & Order of integration \\
\hline LTC & 7.50631 & $\mathrm{I}(1)$ & 198.393 & $\mathrm{I}(1)$ \\
\hline LEPS & 3.22504 & $\mathrm{I}(1)$ & 757.904 & $\mathrm{I}(1)$ \\
\hline LROTA & 20.4457 & $\mathrm{I}(\mathrm{O})$ & 547.500 & $\mathrm{I}(\mathrm{O})$ \\
\hline LLEVERAGE & 10.2318 & $\mathrm{I}(\mathrm{O})$ & 263.509 & $\mathrm{I}(\mathrm{O})$ \\
\hline LCS & 5.51592 & $\mathrm{I}(\mathrm{O})$ & 154.464 & $\mathrm{I}(0)$ \\
\hline
\end{tabular}

The results from the panel unit root test show that all the variables are stationary, while some are stationary at levels and some are stationary after the first difference. For instance, the result shows that compliance and EPS are stationary at the first difference, that is, they are $\mathrm{I}(1)$ variables meaning they are integrated of order one. The remaining variables, such as ROTA, leverage, EPS, and company size, are all stationary at levels, that is, the I(O) variables. The general implication of the panel unit root test results is that all the variables are stationary and are suitable for panel data analysis. 


\subsection{Cross-Sectional Dependence Test of Company Attributes and Compliance Level}

This test is necessary to examine cross-sectional dependence in the residuals of the pool regression. The existence of cross-sectional dependence makes it necessary to use a panel data analysis instead of the pool multiple regression method. The results are presented in Table 6.

Table-6. Cross-sectional dependence test of company attributes and compliance levels.

\begin{tabular}{c|c|c|c}
\hline \multicolumn{1}{c}{ Null hypothesis: No cross-section dependence (correlation) in residuals } \\
\hline Test & Statistic & d.f. & Prob. \\
\hline Breusch \& Pagan LM & 25875.00 & 1035 & 0.0000 \\
\hline Pesaran scaled LM & 544.9560 & & 0.0000 \\
\hline Pesaran CD & 160.8571 & & 0.0000 \\
\hline
\end{tabular}

The results in Table 6 are for the cross-sectional dependence test for the companies' attributes and compliance levels among the 46 companies covered in the survey. The results show that the null hypothesis is rejected across the three tests of cross-sectional dependence. Precisely, the Breusch-Pagan LM, Pesaran scaled LM and Pesaran CD all have probabilities of less than 0.05, which shows that the null hypothesis is rejected, and it is concluded that there is cross-sectional dependence in the residuals of the pool regression. Therefore, panel data analysis is more suitable to estimate the relationship between company attributes and the compliance levels across the 46 companies.

\subsection{Panel Fixed and Random Effects Estimations for Company Attributes and Compliance Level}

After the initial tests, we can now estimate both the fixed and random effects for the impact of company attributes on the level of compliance with IFRS 1 disclosure among the 46 listed firms covered in the study. The results of the fixed and random effects are presented in Tables 7 and 8 , respectively.

Table-7. Fixed effect results for the impact of company attributes on compliance level

\begin{tabular}{l|c|c|c|c}
\hline Variable & Coefficient & Std. Error & t-Statistic & Prob. \\
\hline C & 4.443222 & 0.016655 & 266.7741 & 0.0000 \\
\hline LLCS & 0.003009 & 0.001416 & 2.124506 & 0.0339 \\
\hline LLEPS & -0.031575 & 0.001359 & -23.23315 & 0.0000 \\
\hline LROTA & -0.002147 & 0.000984 & -2.181799 & 0.0293 \\
\hline LLEVERAGE & 0.016579 & 0.001460 & 11.35560 & 0.0000 \\
\hline \multicolumn{4}{|c|}{ Effects Specification } & \\
\hline Cross-section fixed (dummy variables) & Mean dependent variable & 4.427735 \\
\hline R-squared & 0.411202 & S.D. dependent variable & 0.078155 \\
\hline Adjusted R-squared & 0.384974 & Akaike information criterion & -2.703823 \\
\hline S.E. of regression & 0.061292 & Schwarz criterion & -2.484366 \\
\hline Sum squared resid. & 4.132409 & Hannan-Quinn criterion & -2.620982 \\
\hline Log-likelihood & 1604.698 & Durbin-Watson stat & 0.950943 \\
\hline F-statistic & 15.67780 & \multicolumn{4}{c}{ O.000000 } \\
\hline Prob (F-statistic) & \multicolumn{4}{c}{}
\end{tabular}

The results in Table 7 appear to show similarities between those in Table 8. Notwithstanding, the Hausman test is conducted to be able to choose between the fixed effect and the random effect. Coskun, Kirkik, and Coskun (2017) also used the Hausman test in their study. The table below presents the results of the Hausman test conducted for this study. 
Asian Economic and Financial Review, 2021, 11(12): 965-984

Table-8. Random effect results for the impact of company attributes on compliance level.

\begin{tabular}{|c|c|c|c|c|}
\hline Variable & Coefficient & Std. Error & t-Statistic & Prob. \\
\hline $\mathrm{C}$ & 4.443222 & 0.016655 & 266.7741 & 0.0000 \\
\hline LLCS & 0.003009 & 0.001416 & 2.124506 & 0.0338 \\
\hline LLEPS & -0.031575 & 0.001359 & -23.23315 & 0.0000 \\
\hline LROTA & -0.002147 & 0.000984 & -2.181799 & 0.0293 \\
\hline LLEVERAGE & 0.016579 & 0.001460 & 11.35560 & 0.0000 \\
\hline & \multicolumn{2}{|c|}{ Effects Specification } & & \\
\hline & & & S.D. & Rho \\
\hline \multicolumn{3}{|l|}{ Cross-section random } & 0.000000 & 0.0000 \\
\hline \multicolumn{3}{|l|}{ Idiosyncratic random } & 0.061292 & 1.0000 \\
\hline & \multicolumn{2}{|c|}{ Weighted Statistics } & & \\
\hline R-squared & 0.411202 & \multicolumn{2}{|c|}{ Mean dependent variable } & 4.427735 \\
\hline Adjusted R-squared & 0.409145 & \multicolumn{2}{|c|}{ S.D. dependent variable } & 0.078155 \\
\hline S.E. of regression & 0.060076 & \multicolumn{2}{|c|}{ Sum squared resid. } & 4.132409 \\
\hline F-statistic & 199.9098 & \multicolumn{2}{|c|}{ Durbin-Watson stat. } & 0.950943 \\
\hline \multirow[t]{2}{*}{ Prob (F-statistic) } & 0.000000 & & & \\
\hline & \multicolumn{4}{|c|}{ Unweighted Statistics } \\
\hline R-squared & 0.411202 & \multicolumn{2}{|c|}{ Mean dependent variable } & 4.427735 \\
\hline Sum squared resid. & 4.132409 & \multicolumn{2}{|c|}{ Durbin-Watson stat. } & 0.950943 \\
\hline
\end{tabular}

Table-9. Hausman test for the impact of company attributes on compliance level.

\begin{tabular}{c|c|c|c}
\hline Test Summary & Chi-Sq. Statistic & Chi-Sq. d.f. & Prob. \\
\hline Cross-section random & 0.000000 & 4 & 0.0897 \\
\hline
\end{tabular}

The results presented in Table 9 show that the probability of the chi-square is not significant, hence the null hypothesis of the random effect is accepted. The implication is that, going by the results of the Hausman test and despite the similarities in the results between the two, the random effect results are much more suitable for the analysis here. Therefore, the results of the random effect are interpreted accordingly.

From the results of the random effects, it is obvious that each indicator of the company attributes has a different coefficient and hence different degrees of impacts on compliance. First, the coefficient of company size is 0.003009, which is positive and significant. The implication is that company size has a significant impact on compliance level. The positive sign of the variable implies that there is a direct relationship between company size and compliance level, hence, as a company expands, there is more tendency for such a company to want to further comply with IFRS disclosure 1. Therefore, the size of the company is an important factor affecting the compliance level of companies in South Africa regarding IFRS disclosure. Some previous studies also highlighted that the size of the company has an impact on compliance with the common standards (Al Mutawaa \& Hewaidy, 2010; Atanasovski, 2015; Latridis \& Dalla, 2011; Ofoegbu \& Odoemelam, 2018; Yiadom \& Atsunyo, 2014).

Second, another variable used as a company attribute is earnings per share (EPS), which is a profitability index. From the random effect result, the coefficient is -0.031575 , which is negative and significant. The implication is that EPS is an important variable as a company attribute that affects the company's compliance level. Consistent with Khamees (2018), the result further shows that there is a significant inverse relationship, which means that the more they make a profit, the lower the compliance level, and vice versa. In other words, it appears that companies' profitability might be more impressive if they are less compliant with the IFRS 1 disclosure. Notwithstanding, the result has again shown that the profitability level of the companies, as shown by EPS, is important in determining the level of compliance of the companies with elements in the disclosure lists of IFRS 1.

Third, return on total assets (ROTA) is another variable used as a company attribute indicator in the panel model. The coefficient is -0.002147 , which is negative and significant. This similarly implies that ROTA is an important factor driving the compliance level of the companies in South Africa regarding IFRS 1 disclosure. Like EPS, ROTA also exhibits an inverse relationship with the compliance level. This shows that an impressive ROTA may lead to less compliance with IFRS 1 disclosure. It should also be noted that ROTA is sometimes used as a 
profitability index in some studies, therefore the similarity of its results to those of EPS might be understandable. However, this finding is inconsistent with other previous studies. Blay et al. (2019) and Latridis and Dalla (2011) urged that profitability ratios are significantly associated with compliance with IFRS.

The last variable used in the model to proxy company attributes is leverage ratio. The coefficient from the random effect result is 0.016579 . This value is positive and significant, thus implying a significant direct relationship between leverage and compliance level. The implication is that a rise in the leverage ratio of a company is an indication of compliance with the IFRS 1 disclosure. Generally, the result shows that leverage is an important factor that affects the compliance level of the listed companies in South Africa. This outcome is in line with other previous studies, such as Latridis and Dalla (2011). On the other hand, Uyar et al. (2016) and Ofoegbu and Odoemelam (2018) found no association between leverage and compliance with IFRS. Gray (1988) cultural theory stated that the type of accounting systems in companies are different because of different cultures, therefore, findings on leverage and other company attributes can differ.

However, considering the overall significance of the random effect model, the F-statistics probability is 0.000000. This is an indication that the estimated model is statistically significant. It shows that all the variables that are used as proxies for company attributes will jointly influence compliance level significantly.

\subsection{Post-Estimation Test for the Panel Data Analysis of the Impact of Company attributes on Compliance Level}

The only post-estimation test recommended after all the initial diagnostics, which are pre-estimation tests, is the normality test. The results are presented in Figure 3.

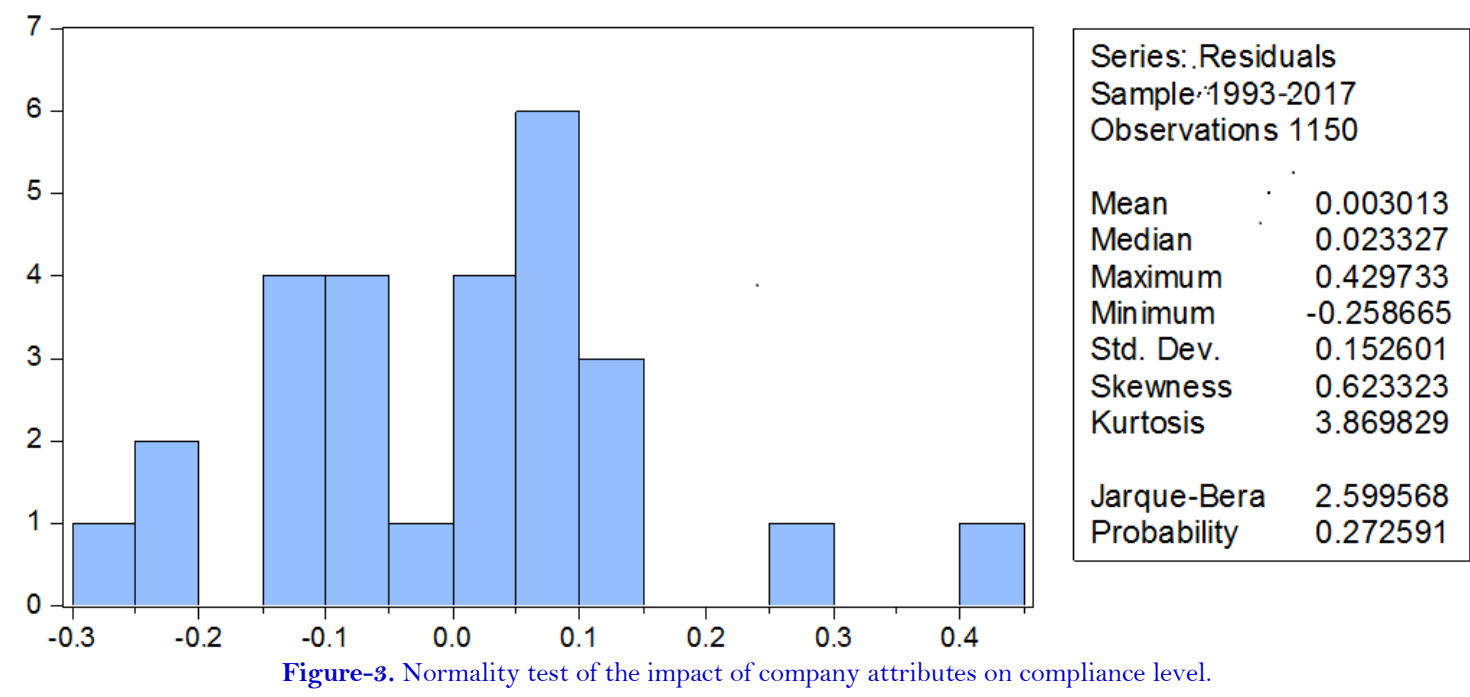

The Jarque-Bera statistics for the normality test are 2.599568 and the probability is 0.272591. This is a clear indication of the existence of a normal distribution pattern in the residual distribution of the estimated panel model. The implication is that the estimated panel model does not have a bias problem, which can reduce the validity of the parameter estimates.

\section{CONCLUSION}

With an average compliance level of 88.21304, it is concluded that South Africa listed firms have significantly complied with IFRS 1. Consistent with Tawiah and Boolaky (2019), who investigated the determinants of IFRS compliance in Africa. They found that the highest level of compliance with IFRS out of thirteen African countries. This study reveals that leverage has a significant positive effect on IFRS 1 compliance. This outcome is in line with Chukwu et al. (2019). The size of a company also has a significant positive effect on compliance with IFRS 1 . This notion was also supported by previous studies (Glaum et al., 2013; Ibrahim, 2015; Uyar et al., 2016). On the other 
hand, the coefficients of EPS and ROTA are negative and significant. This similarly implies that ROTA and EPS are important factors driving the compliance level of companies in South Africa with the IFRS 1 disclosure. EPS and ROTA also exhibit an inverse relationship with compliance level.

The literature revealed that some of countries have achieved high levels of compliance with IFRS. On the other hand, some studies have shown that IFRS did not improve the level of compliance with the common standards. Literature reflected that the level of compliance with the uniform standards differs from company to company. Therefore, continuous studies must be conducted to check if companies are maintaining a high level of compliance with the standards. Differences in the level of compliance from one company to another can be clarified by cultural theory. According to Hofstede (1983), culture can be described as a collective programming of the mind, hard to change, and differentiates a group of humans from others. This definition showed that an organization's culture could differ because people in management have their own unique skills and experience, which automatically affect the company attributes.

This study investigated four company attributes which are leverage, EPS, ROTA and company size. Literature revealed that there are other company attributes which are importance on compliance with the common standards. Further studies could also consider other company attributes such as liquidity, audit size, ownership structure just to mention a few.

\section{ABBREVATIONS}

EPS

IASB

IFRS

JSE

ROE

ROTA

$\mathrm{SP}$

SPSS
Earnings Per Share.

International Accounting Standards Board.

International Financial Reporting Standards.

Johannesburg Stock Exchange.

Return on Equity.

Return on Total Assets.

Share Price.

Statistical Package for the Social Sciences.

Funding: The study is financed by the University of KwaZulu Natal, College of Law and Management Studies, School of Accounting, Economics and Finance, Westville Campus, Durban, South Africa.

Competing Interests: The authors declare that they have no competing interests.

Acknowledgement: A very big thank you to Prof Msizi Mkhize and Dr Omolade Adeleke for their contributions.

\section{REFERENCES}

Adenugba, A. A., Ige, A. A., \& Kesinro, O. R. (2016). Financial leverage and firms' value: A study of selected firms in Nigeria. European Journal of Research and Reflection in Management Sciences, 4(1), 2056-5992.

Aggreh, M., Malgwi, C., Aggreh, M. S., \& Enyi-Igbokwe, A. E. (2018). Does adoption of IFRS affect financial performance evidence from Nigerian deposit money banks? . International Journal of Accounting and Financial Reporting, 8(3), 51-77. Available at: https://doi.org/10.5296/ijafr.v8i3.13309.

Agyei-Mensah, B. K. (2012). The impact of adopting International Accounting Standards 1 (IAS 1) in Ghana: The extent of disclosures, and their relationship to corporate characteristics. African Journal of Business Management, 6(44), 1089610905. Available at: https://doi.org/10.5897/ajbm11.1857.

Akman, N. H. (2011). The effect of IFRS adoption on financial disclosure: Does culture still play a role? American International Journal of Contemporary Research, 1(1), 6-17. 
Al Mutawaa, A., \& Hewaidy, A. M. (2010). Disclosure level and compliance with IFRSs: An empirical investigation of Kuwaiti companies. International Business \& Economics Research Journal (IBER), 9(5), 33-47. Available at: https://doi.org/10.19030/iber.v9i5.566.

Alade, M., Olweny, T., \& Oluoch, O. (2017). Compliance with IFRS and value relevance at the Nigerian stock market. International Journal of Economics, Commerce and Management, 5(7), 109-110.

Alrawahi, F. E., \& Sarea, A. M. (2016). An investigation on the level of compliance with IAS 1 By listed firms in bahrain bourse. International Journal of Islamic and Middle Finance and Management., 9(2), 254-276. Available at: https://doi.org/10.1108/imefm-07-2015-0077.

Asika, E. R. (2018). Effect of IFRS on value relevance of accounting information: Evidence from quoted manufacturing firms in Nigeria. International Journal of Trend in Scientific Research and Development (IJTSRD), 2(5), 2255-2201.

Atanasovski, A. (2015). Empirical investigation into the determinants of compliance with IFRS 7 disclosure requirements. Acta Universitatis Danubius Economia, 11(2), 5-17.

Blaao, M. K. (2016). Financial Analysis by using profitability ratios and its role in evaluating the performance of commercial banks a sample study of commercial banks In Libya. IOSR Journal of Economics and Finance, 7(3), 40-51.

Blay, M. W., Gudjoe, C. S., \& Okyere, D. O. (2019). Corporate compliance with international financial and reporting standards. A case study of selected small \& medium -sized enterprises (SME) in a cape coast metropolis. International Journal of Engineering Technologies and Management Research, 6(1), 1-12.

Cardona, J. R., Karen, C., Castro-Gonzalez, \& Carmen, B. R. (2014). The impact of culture and economic factors on the implementation of IFRS. Accounting and Taxation, 6(2), 29-47.

Chukwu, G. J., Damiebi, I., \& Okoye, E. I. (2019). Firm-specific attributes and the value relevance of accounting information in Nigeria. International Journal of Business and Management, 14(10), 12-20. Available at: https://doi.org/10.5539/ijbm.v14n10p12.

Companies Act. (2008). Companies Act 71 of 2008, South Africa Government Gazette. Vol 526 No 32121.

Cooke, T. E. (1992). The impact of size, stock market listing and industry type on disclosure in the annual reports of Japanese listed corporations. Accounting and Business Research, 22(87), 229-237. Available at: https://doi.org/10.1080/00014788.1992.9729440.

Coskun, S., Kirkik, S., \& Coskun, S. (2017). The effect of independent audit on the disclosure level of income taxation standards: A research on Istanbul stock market food sector. International Journal of Business and Social Science, 8(9), 109-115.

Dzomira, S. (2015). Governance and fraud risk management in the public sector in South Africa. Public and Municipal Finance, $4(3), 25-36$.

Financial Market Act. (2012). South African government, Government Gazzette, Republic of South Africa. Volume 572, Act No 19 of 2012.

Frankfort-Nachmias, C., \& Nachmias, D. (2008). Reseach methods in the social sciences (7th ed.). New York: Worth.

Fuertes-Callen, Y., \& Cuellar-Fernandez, B. (2019). Inter-relationship between firm growth and profitability in a context of economic crises. Journal of Business Economics and Management, 20(1), 86-106. Available at: https://doi.org/10.3846/jbem.2019.6928.

Garg, V., Tiwari, P., \& Shalini, S. (2018). Liquidity and profitability analysis of selected automobile companies. International Journal of Supply Chain Management, 7(4), 94-100.

Ghafoorifard, M., Sheykh, B., Shakibaee, M., \& Joshaghan, N. S. (2014). Assessing the relationship between firm size, age and financial performance in listed companies on Tehran Stock Exchange. International Journal of Scientific Management and Development, 2(11), 631-635.

Ghebregiorgis, F., \& Atewebrhan, A. (2016). Measurement of bank profitability, risk and efficiency: The case of the Commercial Bank of Eritrea and Housing and Commerce Bank of Eritrea. African Journal of Business Management, 10(22), 554-562. 
Glaum, M., Schmidt, P., \& Street, D. (2013). Accounting and business research compliance with IFRS 3-and IAS 36-required disclosures across 17 European countries: Company-and country-level determinants. Accounting and Business Research, 43(3), 37-41. Available at: https://doi.org/10.1080/00014788.2012.711131.

Gray, S. J. (1988). Towards a theory of cultural influence on the development of accounting systems internationally. Abacus, 24(1), 1-15. Available at: https://doi.org/10.1111/j.1467-6281.1988.tboo200.x.

Hofstede, G. (1983). National cultures of four dimensions. International Studies of Management And Organizations, 13(1-2), 45-74. Available at: https://doi.org/10.1080/00208825.1983.11656358.

Ibrahim, K. (2015). The impact of firm characteristics on IFRS and disclosure in a transition period Nigeria. International ournal of Economic Sciences, 4(4), 1-13. Available at: https://doi.org/10.20472/es.2015.4.4.001.

IFRS Foundation. (2012). IFAC IPSASB meeting. Agenda Paper 6.3. Paper 2. A53.

Jensen, M. C., \& Meckling, W. H. (1976). Theory of the firm: Managerial behavior, agency cost, and ownership structure. Journal of Financial Economics, 3(4), 305-360.

Kartikasari, D., \& Merianti, M. (2016). The effect of leverage and firm size to profitability of public manufacturing companies in Indonesia. International Journal of Economics and Financial Issues, 6(2), 409-413.

Khamees, B. A. (2018). Impact of compliance with IFRS disclosure requirements on ERC. Academy of Accounting and Financial Studies Journal, 22(5), 1-17.

Latridis, G., \& Dalla, K. (2011). The impact of IFRS implementation on Greek listed companies: An industrial sector and stock market index analysis. International Journal of Managerial Finance, 7(3), 284-303. Available at: https://doi.org/10.1108/17439131111144478.

Li, L., \& Wang, Z. (2019). How does capital structure change product-market competitiveness? Evidence from Chinese firms. PLoSOne, 14(2), e02 10618. Available at: https://doi.org/10.1371/journal.pone.0210618.

Masca, E. (2012). Influence of culture factors in adoption of the IFRS For SMEs. Procedia Economics and Finance, 3, 567-575. Available at: https://doi.org/10.1016/s2212-5671(12)00197-9.

Mutawaa, A. A. (2010). Disclosure level and compliance with IFRS: An empirical investigation of Kuwait companies. International Business and Economics Research Journals, 9(5), 33.

Myšková, R., \& Hájek, P. (2017). Comprehensive assessment of firm financial performance using financial ratios and linguistic analysis of annual reports. Journal of International Studies, volume 10, issue: 4, 10(4/7), 96-108. Available at: https://doi.org/10.14254/2071-8330.2017/10-4/7.

Nwoye, U. J., Chidoziem, A. M., Obierah, J., \& Ekesiob, i. C. (2017). Nigerian banks and global ranking: The IFRS compliance impact. The Nigerian Act. The Official Journal of the Institute of Chartered Accountants Of Nigeria, 5O(2), 1-37.

Ofoegbu, N. G., \& Odoemelam, N. (2018). International financial reporting standards (IFRS) disclosure and performance of Nigeria listed companies. Cogent Business $\&$ Management, 5(1), 1542967. Available at: https://doi.org/10.1080/23311975.2018.1542967.

Ohlson, J. (1995). Earnings, book values and dividends in equity valuation. Contemporary Accounting Research, 11(2), 661-687. Available at: https://doi.org/10.1111/j.1911-3846.1995.tbo0461.x.

Pacter, P. (2014). IFRS as global standards: A pocket guide. London: IFRS Foundation.

Pacter, P. (2016). IFRS foundation 2016. Pocket guide to IFRS: The Global Financial Reporting Language: IFRS Foundation.

Ponce, H. G., Hlaciuc, E., Mateș, D., \& Măciucă, G. (2016). Empirical study of financial disclosure compliance with IFRS: Evidence from listed Romanian companies. Journal of Accounting and Auditing: Research \& Practice, 2016, 1-15. Available at: https://doi.org/10.5171/2016.794159.

Rutkowska-Ziarko, A. (2015). The influence of profitability ratios and company size on profitability and investment risk in the capital market. Folia Oeconomica Stetinensia, 15(1), 151-161. Available at: https://doi.org/10.1515/foli-2015-0025.

Sarea, A. M., Muslih, A. M., \& Hawaldar, I. T. (2017). Measuring the level of compliances with financial accounting standards No.8: Evidence from Bahrain. Paper presented at the Global Conference on Business and Economics Research 
Tang, P. C., Fu, S., \& Yang, S. (2019). Do peer firms affect corporate social performance? Journal of Cleaner Production, 239, 118080. Available at: https://doi.org/10.1016/j.jclepro.2019.118080.

Tawiah, V., \& Boolaky, P. (2019). Determinants of IFRS compliance in Africa: analysis of stakeholder attributes. International Journal of Accounting \& Information Management, 27(4), 573-599. Available at: https://doi.org/10.1 108/ijaim-09-20180110 .

Tran, T., Ha, X., Le, T., \& Nguyen, N. (2019). Factors affecting IFRS adoption in listed companies: Evidence from Vietnam. Management Science Letters, 9(13), 2169-2 180. Available at: https://doi.org/10.5267/j.msl.2019.7.035.

Tsegba, I., Sember, J., \& Tyokoso, G. (2017). Firm Characteristics and compliance with IFRS by listed Financial Services Companies in Nigeria. Applied Financial and Accounting, 3(1), 83-93. Available at: https://doi.org/10.11114/afa.v3i1.2196.

Tulsian, M. (2014). Profitability analysis (A comparative study of SAIL \& TATA Steel). IOSR Journal of Economics and Finance, 3(2), 19-22. Available at: https://doi.org/10.9790/5933-03211922.

Usman, A. B., \& Ndagi, S. (2019). Does compliance with accounting standards disclosure requirements matter on a value relevance of other comprehensive income items in Nigeria. IBBU Journals, $11(2)$, 55-74.

Uyar, A., Kilic, M., \& Gokcen, B. A. (2016). Compliance with IAS/IFRS and the firm characteristics; Evidence from emerging capital market of Turkey. Economic Research, 29(1), 148-161.

Wadesango, N., Hove, J., \& Kurebwa, M. (2016). Effects of a large class size on effective curriculum implementation. International Journal of Educational Sciences, 12(2), 173-183. Available at: https://doi.org/10.31901/24566322.2016/12.02.09.

Yiadom, E. M., \& Atsunyo, W. (2014). Compliance with IFRS By listed companies in Ghana. International Journal of Business $\&^{\circ}$ Management, 9(10), 87-97. Available at: https://doi.org/10.5539/ijbm.v9n10p87.

Yuliza, A. (2018). The effects of earnings per share and firm size to stock price LQ45 company listed in Indonesian securities. International Journal of Engineering \& Technology, 7(4.9), 247-249 Available at: https://doi.org/10.14419/ijet.v7i4.9.21089.

Zehri, F., \& Chouaibi, J. (2013). Adoption determinants of the International Accounting Standards IAS/IFRS by the developing countries. Journal of Economics Finance and Administrative Science, 18(35), 56-62. Available at: https://doi.org/10.1016/s2077-1886(13)70030-1.

Views and opinions expressed in this article are the views and opinions of the author(s), Asian Economic and Financial Review shall not be responsible or answerable for any loss, damage or liability etc. caused in relation to/arising out of the use of the content. 